\title{
AYURVEDIC MEDICINAL IMPORTANCE OF SHANKHPUSHPI (CONVOLVULUS PLURICAULIS): POTENTAIL COGNITION BOOSTING HERB
}

\author{
Shifali Thakur ${ }^{1}$, Hemlata kaurav ${ }^{2 *}$ \\ \#1-Shuddhi Ayurveda, JeenaSikhoLifecare Pvt. Ltd. Zirakpur 140603, Punjab, India. \\ 9501198761,Thakurshifalithakur123@gmail.com \\ \#2- Shuddhi Ayurveda, JeenaSikhoLifecare Pvt. Ltd. Zirakpur, 140603, Punjab, India. \\ 9736140010, shuddhi.research@jeenasikho.co.in
}

\begin{abstract}
India is enriched in a diversity of plants since past times. Herbal plants are indigenous and very potent that consider a gift of nature. Shankhpushpi (Convolvulus pluricaulis) is known as a Medhya (brain tonic) Rasayana in the Indian traditional system. The medicinal herb is considered to enhance certain aspects related to intellect and memory improvement. Shankhpushpi is a Sanskrit word that means "the plant with flowers shaped like a conch. It is a perennial herb which seems like morning glory. The shankha is one of Lord Shiva's sacred instruments. It consists of various phytochemical constituents mainly in the form of proteins, amino acids and the alkaloids convolvine. Many types of research have been done on the Convolvulus pluricaulis plant and showed various therapeutic and pharmacological activities. It includes nootropic activity, antidepressant, antistress, anxiolytic, antioxidant, antidiabetic, cardiovascular activity and many others. Thus this medicinal plant is playing a vital role in the medical field. The present review is a summary of the phytomedicinal importance of Convolvulus pluricaulis in the traditional medicinal system as well as the modern system.

Keywords: Convolvulus pluricaulis, Shankhpushpi, Nootropic, Ayurveda, Alcohol
\end{abstract}

\section{INTRODUCTION}

Herbal drugs are gaining popularity in the field of medicine in both developing and developed countries because of their natural origin and fewer side effects [1]. Human recognized their dependence on nature for a healthy life. Humanity has depended on the diversity of plant resources for food, clothing, shelter and medicine to cure myriads of ailments [2]. Plants are the principal source of natural compounds that possess biological and pharmacological activities $[3,4,5]$. The phytochemical constituents are extracted from the plant. They have been used in both traditional and modern medicine in the world [6,7].In India, Shankhpushpi is utilized mostly in Ayurvedic pharmacopeia. All the parts of the plant are considered as a therapeutic source for various human diseases. Shankhpushpi was consisting of the whole plant of Convolvulus pluricaulis, Evolvulusalsenoids, Citoreaternatea, Lavendulabipinnata and Canscoradecussata. Plants other than $C$. pluricaulis use the name Shankhpushpi in different parts of the country. Further studies have been established that Convolvulus pluricaulis is the plant species that should be taken in the name of Shankhpushpi [8]. Convolvulus is a genus of the Convolvulaceae family [9]. Convolvulaceaeis known as the morning glory family of the plants that are covering over 1880 species in 57 types [10]. The quality standard of $C$. pluricaulis was published by the Indian Council of Medical Research [11]. The number of researches proved their scientific potential in the central nervous system, depression, anxiolytic, tranquilizing, antidepressant, antistress, neurodegenerative, anti-amnesia, antioxidant, hypolipidemic, immunomodulatory, 
analgesic, antifungal, antibacterial, antidiabetic, antiulcer, anticatatonic, and cardiovascular, antidiabetic, antiulcer, anticatatonic and cardiovascular activity [12]. Shankhpushpi is a Sanskrit word that means "the plant with flowers shaped like a conch". According to Hinduism, Shankha is one of the sacred instrument of Lord Shiva. The plant is widely distributed in southern parts of India, Sri Lanka and Myanmar. It is mostly cultivated above an altitude of $1300 \mathrm{~m}$. It consists of various phytochemical compounds like xanthones, triterpenoids, loliolide, sterols and flavonoids [13,14]. Many types of research have been done on the Convolvulus pluricaulis plant and showed various therapeutic and pharmacological activities. It includes nootropic activity, antidepressant, antistress, anxiolytic, antioxidant, antidiabetic, cardiovascular activity and many others. Vernacular names and Taxonomy of Convolvulus pluricaulis is given in table 1 and 2 respectively.

Table 1. Vernacular names of Convolvulus pluricaulis

\begin{tabular}{|l|l|}
\hline English & speedwheel \\
\hline Hindi & Shankhpushpi, Aparajit \\
\hline Sanskrit & Sankhapuspi \\
\hline Urdu & Sankhali \\
\hline Punjabi & Shankhpushpi \\
\hline Bengali & Sankhapuspi \\
\hline Kanarati & Shankhavali \\
\hline Malayalam & Bilikanthisoppu \\
\hline Marathi & Krsnakranti, Vishnukranthi \\
\hline Oriya & Shankhabela \\
\hline Tamil & Krishna-enkranti \\
\hline Tibetan & Sanghupushpam, kakkurattai \\
\hline Telugu & Shankhapushpi \\
\hline
\end{tabular}

Table 2. Taxonomical classification of Convolvulus pluricaulis

\begin{tabular}{|l|l|}
\hline Taxonimical Rank & Taxon \\
\hline Kingdom & Plantae \\
\hline Sub Kingdom & Tracheobionta \\
\hline Division & Magnoliophyte \\
\hline Class & Magnoliopsida \\
\hline Order & Solanales \\
\hline Family & Convolvulaceae \\
\hline Genus & Convolvulus \\
\hline Species & Pluricaulis \\
\hline Common Name & Shankhpushpi \\
\hline
\end{tabular}




\section{BOTANICAL DESCRIPTION OF CONVOLVULUS PLURICAULIS}

C. pluricaulis (Figure 1) is a perennial plant. The branches of $C$. pluricaulis are widely spread on the ground and long up to $30 \mathrm{~cm}$. Roots are usually branched, cylindrical, ribbed having some rough stem nodules. Small roots are 1-5cm long, 0.1-.04 cm thick. The color of the root changes from brown to light brown. Stems are cylindrical with hairy nodes and internodes. Leaves are shortly petiolate linear-lanceolate, acute, hairy on both surfaces. Leaves are 10.5-2 $\mathrm{cm}$ long and $0.1-0.5 \mathrm{~cm}$ broad light green in color. Flowers are white or purple. It is solitary or in pairs sessile or sub-sessile in the leaf axis Fruits are capsuled, oblong globose with coriaceous, pale brown pericarp. Seed are minutely puberulous and brown in color [15].

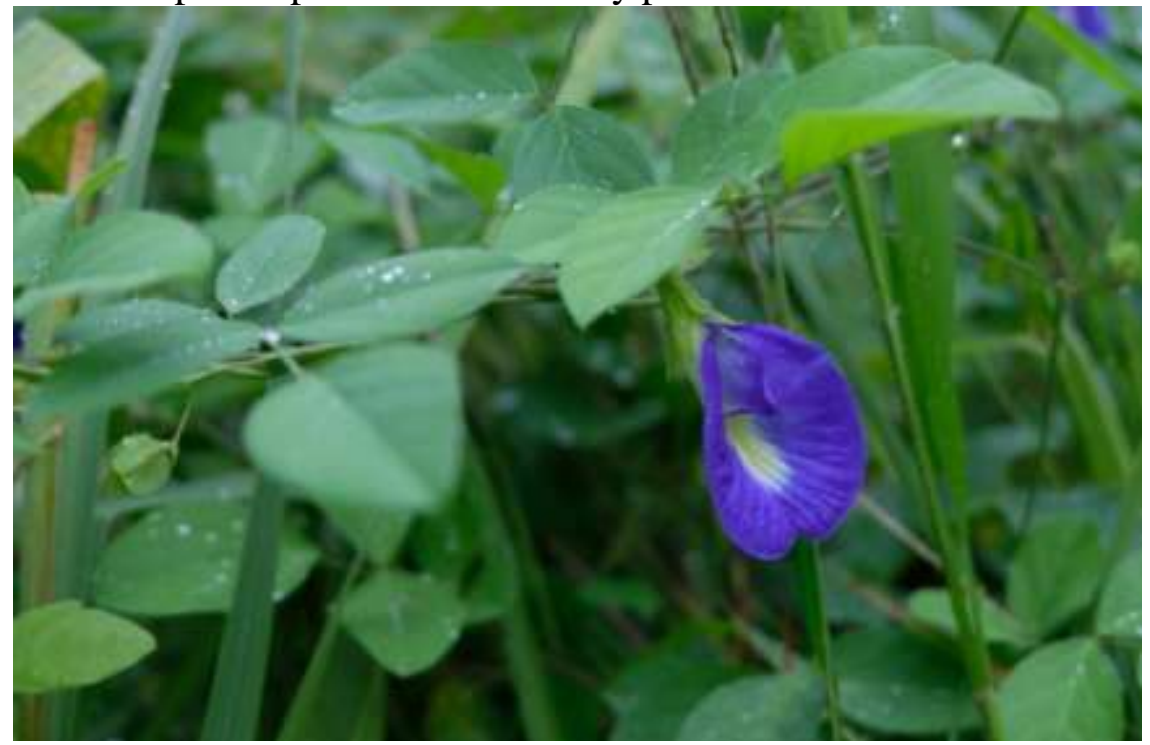

Figure 1. Convolvulus pluricaulis (Shankhpushpi)

\section{GEOGRAPHICAL DESCRIPTION OF CONVOLVULUS PLURICAULIS}

Convolvulus species are distributed all over the world. But the plant convolvulus pluricaulis is mostly cultivated in areas with a Mediterranean climate and in semi-desert regions. In India, C. pluricaulis is known from the margins and within the Sahara and Sind desert [16]. It is widely distributed in Gujarat, Konkan, Sindh and Bihar. It is found all over in rainy season $[17,18]$

\section{PHYTOCHEMICAL CONSTITUENTS OF CONVOLVULUS PLURICAULIS}

There are various chemical constituents isolated from Shankhpushpi like Carbohydrates-Dglucose, rhamnose, maltose, sucrose and starch. It also contains protein, amino acids and the alkaloids-convolvine, convosine, subhirsine and convolvidine along with fatty acid and wax constituents, hydrocarbons, aliphatic and sterol and certain other bio-chemicals [18].

1. Carbohydrates: D-glucose, maltose, rhamnose, sucrose, starch and other carbohydrates $[19,20]$.

2. Fatty acids/ Volatile oil/ Fixed oil: Fatty alcohols [21] and hydrocarbons, 30.9\% myristic acid, 66.8\% palmitic acid and 2.3\% linoleic acid and hextriacontane [22,23].

3. Protein and Amino acids: Proteins and amino acids are also isolated from the plant.

4. Phenolic/Glycosides/Triterpenoid/Steroids: Deshpande et al., reported a chemical examination of the whole plant of C. pluricaulis and found the presence of scopoletin, $\beta$ sitosterol and ceryl alcohol [5]. Choloroform fraction of this contains 20-oxodotriacontanol, tertratriacontanoic acid and 29-oxodotriacontanol, flavonoid-kampferol, steroidsphytochemical [4]. CP-1 is a phytochemical marker that has been isolated and characterized by the HPTLC technique [24,25,26,27]. 


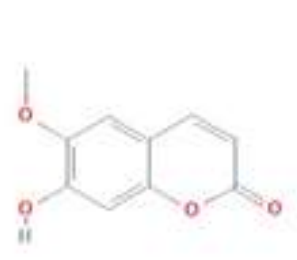

a. Scopoletin

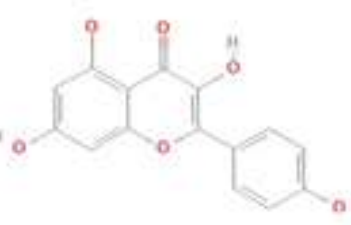

e. Kaempferol

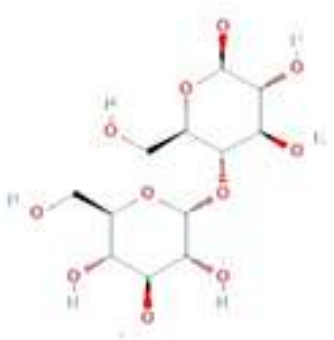

i. Maltose

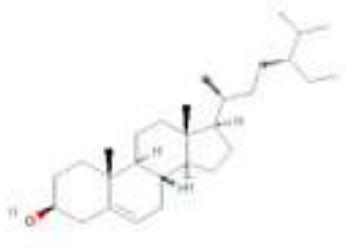

b. $\beta$-sitosterol

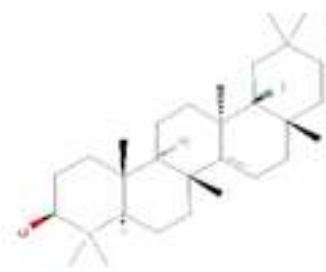

f. Taxaxerol

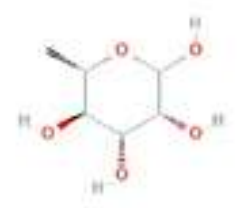

j. Rhamnose

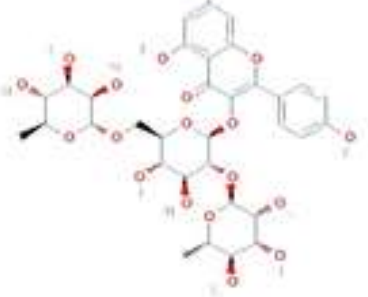

c. Cliterin

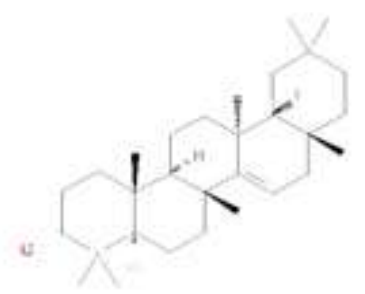

в. Taraxerone

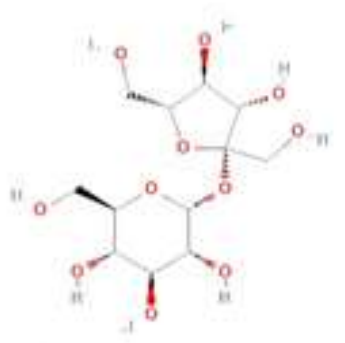

k. Sucrose

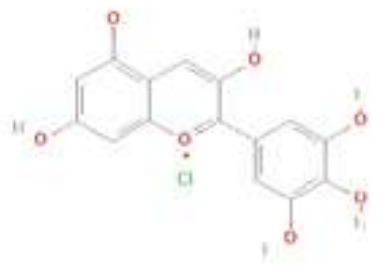

d. Delphinidin

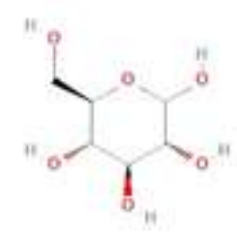

h. D-glucose

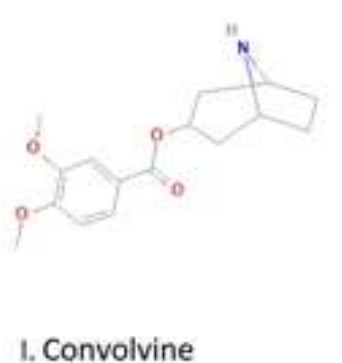

Figure 2. Chemical structure of some major constituents of C. pluricaulis(Shankhpushpi)

\section{TRADITIONAL AND MODERN VIEW}

\section{A. AYURVEDIC VIEW}

Convolvulus pluricaulis is a common plant in southern India. The herb is quoted to be Soubhagyakarana and Vasikarana in Vedas. There are various synonyms used for shankhpushpi in Ayurveda like Nyastika, Subhangakarani, Sahasraparni, samvanani, samuspala, babhru, kalyani etc. According to Acharya Charak Shankhpushpi is one of the best "medhya drug" in MedhyaRasayana. Brihttrayi has mentioned Shankhpushpi's limited number of times and they did not include it in any Gana or Varga. Dhanvantarinighantu mentioned only one variety of Shankhpushpi. Sodhala mentioned both varieties red (Raktapuspika) and blue flowered (Nilapushpa) and Kaiyadevnighantu described two varieties like Shankhpushpi and Sarpakshi. Bhavamishra quoted it in two varieties like white (Shvet) and blue (Nila) varieties [28]. The rasa Panchak and description of this herb according to nighantus are mentioned in table no. 3 and table no. 4 accordingly.

Table 3: Rasa Panchak of Shankhpushpi [29]

\begin{tabular}{|l|l|}
\hline Sanskrit/English & Sanskrit/English \\
\hline Rasa/Taste & Katu,Kashaya/Astringent,Bitter \\
\hline Guna/Physical Properties & Guru,Sara,Snigdha,Pichchila/Heavy,oily \\
\hline Virya/Potency & Ushna/ Hot \\
\hline Vipaka/Metabolic property & Madhura/ Sweet \\
\hline
\end{tabular}


Table 4: Description of Shankhpushpi in Nighantus

\begin{tabular}{|l|l|}
\hline 1. DhanvantariNighantu & $\begin{array}{l}\text { It quoted this herb in KarviradiVarga. It explained } \\
\text { shankhpushpi as a medhya and Rasayana drug. It is } \\
\text { utilized in Vishachikitsa (toxicity), ApasmarChikitsa } \\
\text { (Epilepsy) and Bhootchikitsa (Psychological diseases) } \\
\text { [30] }\end{array}$ \\
\hline 2. KaiyadevNighantu & $\begin{array}{l}\text { According to this, Shankhpushpi is said to be Medhya } \\
\text { and Rasayana. It is also utilized in Apasmar (epilepsy), } \\
\text { Kushtha (skin related), Bhoot, Visha (toxicity) and } \\
\text { krimi-chikitsa (parasitic infections) [31]. }\end{array}$ \\
\hline 3. ShodhalNighantu & $\begin{array}{l}\text { It quoted Shankhpushpi in KarviradiVarga. There is } \\
\text { incomplete description of shankhpushpi in } \\
\text { ShodhalNighantu [32]. }\end{array}$ \\
\hline 5. BhavprakashNighanti & $\begin{array}{l}\text { Shankhpushpi is described in AbhyadiVarga. It is also } \\
\text { known as Kiriti, kambumalini, Shankhahuli, } \\
\text { Shankhnagni. This is also utilized as Medhya, Rasayana, } \\
\text { Intellect promoter and as cognitive drug [33]. }\end{array}$ \\
$\begin{array}{l}\text { According to this, Shankhpushpi is described in } \\
\text { GuruchyadiVarga. Shankhavaha, Manglayakusuma are } \\
\text { the synonyms given to the plant. It also mentioned } \\
\text { shankhpushpi to be utilized as medhya (mind } \\
\text { rejuvenator), Vrishya (Aphrodsic), manasroghrit, } \\
\text { rasayana, and a cognitive drug. It also to be } \\
\text { recommended in Kushtha, krimi and vishachikitsa, } \\
\text { shankhpushpi is said to be Kasaya and Ushna [34]. }\end{array}$ \\
$\begin{array}{l}\text { It described Shankhpushpi in Guruchydivarga. It } \\
\text { described as a drug that promotes intellect and helps to } \\
\text { improve voice quality [35] }\end{array}$ \\
\hline 6. Raj Nighantu
\end{tabular}

\section{Actions of Shankhpushpi according to Ayurveda}

Medhya - promotes the intellectual capacity

Swarakarini - improves voice

Grahabhootadidoshaghni - useful in diseases of supernatural origin

Rasayani- rejuvenates the body

Kantida- enhances the aura of the body and gives it a healthy look

MajjadhatuRasayana - rejuvenates the nervous tissue

Unmadaghna - alleviates insanity and emotional instability

Vrishya- aphrodisiac

Pachanbala- increases the strength of the digestive system

Chedana- Laxative

Nidrajnana- promotes sleep

Various Formulations of Shankhpushpi described in Charak Samhita [36]

PrathamBrahmarasayana, Dwitiya Brahmarasayana, IndraRasayana, MedhyaRasayana, Brahmi Ghrit, Brahmi Ghrit + Shankhpushpi, AgstyaHaritaki

Various Formulations of Shankhpushpi described in AstangHridya [37]

AgstyaHaritaki, TalvavagunthanVidhi, AstangGhrit, Brahmi Ghrit, Brahma Rasayana, MedhVridhikarRasayana,BrahntiaadiRasayanaYog Various Formulations of Shankhpushpi described in Sharangdhar Samhita [38]

BrahmiaadiSwarasa, Agstyaharitkyaavaleh, Bindughritam 


\section{B. FOLK VIEW}

Ethnobotanical research into medicinal plants is becoming an important part of Indian research and has been included in advanced research during recent years. Plants have much relevance to socioeconomic and socio-religious aspects of Human life in India. It is an herb that has been utilized in India for hundreds of years for many disorders such as stress, anxiety and insomnia and promotes longevity and prevents diseases by providing strength and immunity. Shankhpushpi is a Sanskrit word. It is the combination of two words shankh+pushpa in this shankh means a marine shell and Pushpa means flower. Shankha is one of Lord Shiva's sacred instruments often used in ritual worship. Therefore, shankhpushpi means the plant with flowers shaped like a conch. This herb is utilized for centuries in India for the treatment of many ailments like anxiety, insomnia and to promote longevity and prevent diseases by providing strength and immunity. According to literature tribal in Chhindwara, Madhya Pradesh describes the plant as an anthelmintic, good in dysentery and also for cure skin ailments and reduces high blood pressure. The leaves of the plant are recommended for mental disturbance and depression by the locals of Gonda, Uttar Pradesh $[39,40,41,42]$.

\section{MODERN VIEW}

In modern times the herbal drugs are preferred more due to their several advantages over modern synthetic drugs made up of inorganic sources. Herbal drugs have negligible adverse impacts on the living systems also these are less expensive than synthetic drugs. But due to increasing market demand for these herbal drugs their quality is getting degraded due to factors like adulteration and contamination $[43,44,45]$. Unintentional adulteration of herbal drugs is induced by misidentification of species or sometimes by misidentification of plant parts. It is most probably happened due to the conflict in similarities of vernacular names as well as scientific names of various medicinal plants. And this practice is directly or indirectly associated with the degradation of herbal drugs [46]. For instance, M. malabrica (false nutmeg) is the most common adulterant which is used in true mace herbal drugs [47]. Intentional adulteration is the primary reason behind the degradation of herbal drugs which is induced to derive maximum profit. It is done by using either orthodox drugs or by the substitution of inferior products or by adding foreign particles which are most commonly called as contaminants such as sand, metals, soil etc. [48,49,50]. Mercury, arsenic, and lead, cadmium, copper and thallium, pesticides, microbes and mycotoxins are the most commonly used contaminants in herbal drugs [51,52,53,54,55,56,57]. Powders, capsules, extracts are the commonly available forms of herbal drugs in the market. Usually, adulterants are added to the herbal drugs either before the processing phase or during the processing phase. Proper quality analysis and standardization protocols are needed to be applied during these phases so that the health risk can be avoided $[58,59,60]$. Standardization ensures the quantity and quality of the herbal drugs [61]. The most preferred technique in today's time is the standard DNA barcode which significantly works on the identification of species [62]. Shankhpushpi is a potent herb that is used in many medicines currently available in India. The formulations are made up of mixing of many plant extracts or powders including Convolvulus pluricaulis. These formulations are complex preparations of compounds medicines and involve several processes. Some preparations have been subjected to clinical trials [63].

Remem (Zydus Industries, India): These medicines are coming in the syrup, tablets. There are 10 species included in this like Centellaasiatica, Celastruspaniculatus, Convolvulus pluricaulis, Asparagus racemosus, Acoruscalamus, Embeliaribes, Tinosporacordifolia, Achyrantesaspera, Terminalia chebula, Saussurealappa. 
Tirukati: There are 13 species included in this medicine. It included Bacopamonnieri, Convolvulus pluricaulis, Centellaasiatica, Asparagus racemosus, Valerianawallichi, Ruerariatuberosa, Saussurealappa, Embeliaribes, Tinosporacordifolia, Operculinaturpethum, Pavoniaodorata, Caryophyllusaromaticus, Foeniculumvulgare.

Ayumeno: It was formulated by Welexlabs, India. 5 species used in this formulation like Centellaasiatica, Convolvulus pluricaulis, Celastruspaniculatus, Withaniasomnifera, Asparagus racemosus.

Abana (The Himalaya Drug and Co. India): Medicines are coming in the form of tablets and syrup. It included 19 species: Centellaasiatica, Convolvulus pluricaulis, Celastruspaniculatus, Balsamodedronmukul, Ocimum sanctum, NardostachysJatamansi, Piper longum, Carumcopticum, Zingiberofficinalis, Cyperusrotundus, Acoruscalamus, Embeliaribes, Syzygiumaromaticum, Santalum album, Elettariacardamomum, Foeniculumvulgare, Rosa damascene, Cinnamomum cassia, Crocus sativus.

Tejras (Sandu Brothers, India): 12 species included in the formulation like Centellaasiatica, Convolvulus pluricaulis, Celastruspaniculatus, Eclipta alba, Cynodondactylon, Asparagus racemosus, Withaniasomnifera, NardostachysJatamansi, Acoruscalamus, Zingiberofficinalis, VetiveriaZizanoides.

Shankhapushpi (Unjha Pharmacy, India): The formulation comes in the form of syrup and it includes 6 species: Convolvulus pluricaulis, Centellaasiatica. NardostachysJatamansi, Nepeiahindostana, Nepeiaelliptica, Onosmabrateatum.

\section{REPORTED PHARMACOLOGICAL STUDIES OF CONVOLVULUS PLURICAULIS}

Various studies have been conducted on this plant to know its pharmaceutical and therapeutic uses. Large-scale clinical studies are still needed to prove the clinical efficacy of this herb, especially in stress-related diseases, neuronal disorders and antidepressants. Some reported studies on Convolvulus pluricaulis are shown below:

1. Nootropic Activity: From reported studies, it was investigated that the ethanolic extract of Convolvulus pluricaulis and its ethyl acetate and aqueous fractions were possessing nootropic activity. Two doses of 100 and $200 \mathrm{mg} / \mathrm{kg} / \mathrm{p}$.o of ethyl acetate and aqueous fractions were given to rats in separate groups. Both the doses of Convolvulus pluricaulis proved to be significant for memory and learning in rats [64]. This activity was assessed with passive and active avoidance paradigms using Cook and Weidley's pole climbing apparatus and elevated plus-maze as models.

One more study was conducted to find out the nootropic property of Shankhpushpi. Three plants i.e. Convolvulus pluricaulis, Clitoriaternatea, Evolvulusalsinoides were evaluated for the nootropic activity using RPM, Porsolt's swim despair and actophotometer models. The results showed that all three plants possess nootropic, anxiolytic and CNS- depressant activity but $C$. pluricaulis plant showed a true source for memory enhancement [65].

\section{Anxiolytic, Antidepressant, Antistress, Neurodegenerative and Antiamnesic activity:}

From various studies it was investigated that $C$. pluricaulis possess antagonist activity. The alcoholic extract of $C$. pluricaulis was investigated to cause an antagonist effect against amphetamines and tremorine $[66,67]$.

A study was conducted to evaluate the effect of petroleum ether, chloroform, and ethyl acetate fraction of the ethanolic extract of $C$. pluricaulis on the depressed mice. It was administrated orally for 10 successive days to separate groups of Swiss young male albino mice. The effects on mice's immobility periods were assessed in the forced swim test (FST) and tail suspension test (TST). The result showed that only chloroform fraction in doses of 50 and $100 \mathrm{mg} / \mathrm{kg}$ significantly reduced the immobility time in both FST and TST [68]. 
From a reported study it was found that the methanolic extract of the $C$. pluricaulis produced an alteration in the general behavior pattern, reduction in motor activity, hypothermia, reduction in exploratory behavior pattern and suppression of aggressive behavior in the animal model [69].

One more study was conducted on the albino rats to evaluate Antiamnesic property. The dose of $C$. pluricaulis $(100 \mathrm{mg} / 100 \mathrm{~g}$ body weight) was given to the model. The result showed lesser effects than diazepam but higher than that of Centellaasiaticalinn, urban Hydrocotyleasiatcalinn [70,71,72,73,74,75].

3. Effect on Thyroid Function: One more study was conducted on the hyperthyroid mice. The root extract of Convolvulus pluricaulis was administrated in the model for 30 days. It was found that the plant extract-induced inhibition in thyroid function and mediated through T4 to T3 conversion [76,77].

4. Antioxidant activity: Nahata et al., reported that the ethanolic extract of $C$. pluricaulis possesses significant antioxidant activity.

5. Hypolipidemic activity: From a reported study it was found that the ethanolic extract of C. pluricaulis possesses hypolipidemic activity. The extract was administrated to Cholesterol fed gerbils. Results showed a reduction in serum cholesterol, LDL cholesterol, triglycerides and phospholipids significantly after 90 days [78].

6. Analgesic Activity: Sharma et al., investigated analgesic activity of $C$. pluricaulis in the mice. The extract of $C$. pluricaulis was caused a reduction in the fighting behavior in the model but didn't show analgesic property although it potentiated morphine analgesia.

7. Antimicrobial activity: $C$. pluricaulis plant was bioassayed by the leaf disc method by feeding deterrence using Spilosoma oblique walker as a text insect. A new compound, 29oxodotriacontanol was isolated from the chloroform fraction of this plant which was found to be a significant antifeedant constituent whereas another compound, tetratriacontanoic acid was discovered for the first time in this plant [79].

8. Antidiabetic Activity: Alam et al, was reported that $C$. pluricaulis plant possesses antidiabetic activity. The extracts were found to be an effective remedy for the treatment of diabetes [80].

9. Antiulcer and anticatatonic activity: Sairam et al., investigated the antiulcerogenic activity of the fresh juice of $C$. pluricaulisin rat model. The model was artificially injected with ethanol and aspirin to cause gastric ulcer in the stomach. C. pluricaulis was given orally twice daily in the doses of 375 and $750 \mathrm{mg} / \mathrm{kg}$ body weight. Results showed anti-ulcerogenic effects in the rats[81].

10. Effect on Reproductive system: Singh et al., was reported in their study that the juice of the $C$. pluricaulis plant prevents excessive menstruation. The fine paste of the plant is helpful for the treatment of abscesses [82].

11. Cardiovascular activity: From the reported studies it was found that total water-soluble extract of the $C$. pluricaulis plant caused a marked and prolonged hypotension in dogs and also reduced the frog myocardium. Ethanolic extract of the plant exerted a negative 
ionotropic action on amphibian and mammalian myocardium. It also deployed spasmolytic activity on smooth muscles $[83,84,85]$

12. Alcohol Addition: A study was conducted on the mice to investigate the effect of shankhpushpi as an anti-additive drug. The effect of churna of shankhpushpi was measured on ethanol withdrawal anxiety in mice model using elevated plus maze. Results showed that shankhpushpi churna reversed ethanol withdrawal anxiety and also decreased chronic alcohol consumption in these mice in a GABA receptor-dependent manner [86].

13. Anthelmintic Activity: Shankhpushpi is a highly bitter in taste and also known as anthelmintic drug. In-vitro study was conducted on the six adult Indian earthworms and cattle worms to evaluated the anthelmintic effect. It was found that shankhpushpi is effective on the earthworm and has anthelmintic activity [87].

Table 5: Reported therapeutic and pharmacological properties of Convolvulus pluricualis

\begin{tabular}{|c|c|c|c|c|}
\hline S. No. & Extract & $\begin{array}{l}\text { Method } \\
\text { (in vivo/ } \\
\text { in-vitro) }\end{array}$ & Pharmacological Activity & References \\
\hline 1 & $\begin{array}{l}\text { Ethanolic } \\
\text { Extract/ Ethyl } \\
\text { Acetate }\end{array}$ & Rat Model & Nootropic Activity & 64 \\
\hline 2 & $\begin{array}{l}\text { Alcoholic } \\
\text { Extract }\end{array}$ & In-vivo study in Rats & Antagonist & 66,67 \\
\hline 3 & $\begin{array}{l}\text { Petroleum } \\
\text { ether, } \\
\text { chloroform, } \\
\text { ethyl acetate } \\
\text { fraction of } \\
\text { Ethanolic } \\
\text { extract }\end{array}$ & $\begin{array}{l}\text { Swiss young male } \\
\text { albino mice }\end{array}$ & Anti-depressant & 68 \\
\hline 4 & $\begin{array}{l}\text { Methanolic } \\
\text { Extract }\end{array}$ & Rat Models & Anti-stress & 69 \\
\hline 5 & Root extract & $\begin{array}{l}\text { In -vivo study in } \\
\text { Albino mice }\end{array}$ & Neurodegenerative & $\begin{array}{l}70,71,72,73, \\
74,75\end{array}$ \\
\hline 6 & Root extract & $\begin{array}{l}\text { In-vivo study in } \\
\text { hyperthyroid mice }\end{array}$ & Effect on thyroid & 76,77 \\
\hline 7 & $\begin{array}{l}\text { Ethanolic } \\
\text { Extract }\end{array}$ & $\begin{array}{l}\text { In -vivo study in } \\
\text { cholesterol fed gerbils }\end{array}$ & Hypolipidemic & 78 \\
\hline 8 & Root extract & Mice Model & Analgesic Activity & 79 \\
\hline 9 & $\begin{array}{l}\text { Water soluble } \\
\text { extract }\end{array}$ & $\begin{array}{l}\text { In vivo study in } \\
\text { Dog/frog }\end{array}$ & Cardiovascular & $83,84,85$ \\
\hline 10 & Root extract & Mice model & Alcohol Addition & 86 \\
\hline
\end{tabular}

\section{TOXICOLOGICAL ASSESSMENT}

The mice model treated with extracts of $C$. pluricaulis plant showed a sedative effect at doses higher than $200 \mathrm{mg} / \mathrm{kg}$ and reflected a moderate to the marked decrease in locomotor activity. The activity lasted for 1-2 hours. The decrease in motor activity due to spontaneous motor activity was observed during the study. At a higher dose animals died due to respiratory distress [88]. 


\section{CONCLUSION}

Convolvulus pluricaulis is utilized as folk medicine to cure different diseases. According to the Indian Traditional system (Ayurveda), Shankhpushpi is considered as one of the most significant plant and the best nootropic agent. It is a primary source from where we get carbohydrates, proteins, amino acids, starch and volatile oils. These are the class of phytochemicals that are utilized as the main constituent in numerous formulations endorsed for several ailments. It is referred as an antioxidant, antidiabetic, antagonist, antidepressant, cardiovascular and many others. It is specially used as a cognitive boosting agent. As this herb is very bitter and pungent, so there is a need to develop its herbal formulation with improved taste for better patient compliant.

\section{ACKNOWLEDGMENT}

Authors are thankful to the Department of Research and Development of JeenaSikhoPvt. Ltd. ZirakpurPunjab for giving us the opportunity to explore this ancient medicinal plant.

\section{CONFLICT OF INTEREST}

None

\section{REFERENCES}

1. Fatima A, Agrawal P, Singh PP. Herbal option for diabetes: an overview. Asian Pac J Trop Dis 2012; 2(suppl 1): S536-S544.

2. Agarwal P, Alok S, Fatima A, Singh PP. Herbal remedies for neurodegenerative disorder (alzheimer's disease): a review. Int J Pharm Sci Res 2013; 4(9): 3328-3340.

3. Abdolshahi, A., Naybandi-Atashi, S., Heydari-Majd, M., Salehi, B., Kobarfard, F., Ayatollahi, S. A., ... Sharifi-Rad, J. Antibacterial activity of some Lamiaceae species against Staphylococcus aureus in yoghurt-based drink (Doogh). Cellular and Molecular Biology (Noisy-le- Grand, France), 2018. 64(8), 71-77.

4. Mishra, A., Saklani, S., Salehi, B., Parcha, V., Sharifi-Rad, M.,Milella, L., ... Srivastava, M. Satyriumnepalense, a high altitude medicinal orchid of Indian Himalayan region: Chemical profile and biological activities of tuber extracts. Cellular and Molecular Biology (Noisy-le- Grand, France), 2018. 64(8), 35-43.

5. Salehi, B., Valussi, M., Jugran, A. K., Martorell, M., Ramírez-Alarcón, K., Stojanović-Radić, Z. Z., ... Sharifi-Rad, M. Nepeta species: From farm to food applications and phytotherapy. Trends in Food Science \& Technology, 2018. 80, 104-122.

6. Prakash, A. M., Sharifi-Rad, M., Shariati, M., Mabkhot, Y., Al-Showiman, S., Rauf, A., ... Sharifi-Rad, J. Bioactive compounds and health benefits of edible Rumex species-A review. Cellular and Molecular Biology (Noisy-le-Grand, France), 2018. 64(8), 27-34.

7. Sharifi-Rad, J., Sharifi-Rad, M., Salehi, B., Iriti, M., Roointan, A., Mnayer, D. Afshari, A. In vitro and in vivo assessment of free radical scavenging and antioxidant activities of Veronica persicaPoir. Cellular and Molecular Biology (Noisy-le-Grand, France), 2018. 64(8), 57-64.

8. Ministry of Health and Family Welfare, Department of Indian Systems of Medicine and Homeopathy. The Ayurvedic Pharmacopoeia of India. New Delhi: Controller of Publications; 2001.

9. Austin DF. Evolvulusalsinoides (Convolvulaceae): an American herb in the old world. Journal of ethnopharmacology. 2008 May 8;117(2):185-98.

10. Staples GW. Revision of Asiatic Poraneae (Convolvulaceae)-Cordisepalum, Dinetus, Duperreya, Porana, Poranopsis, and Tridynamia. Blumea-Biodiversity, Evolution and Biogeography of Plants. 2006 Dec 8;51(3):403-91. 
11. Gupta AK, Tandon N, Sharma M. Quality standards of Indian medicinal plants. New Delhi: Indian Council of Medical Research; 2005.

12. Sethiya NK, Nahata A, Mishra SH, Dixit VK. An update on Shankhpushpi, a cognitionboosting Ayurvedic medicine. Zhong Xi Yi Jie He XueBao 2009; 7(11): 1001-1022.

13. Sethiya NK, Patel MB, Mishra SH. Phyto-pharmacologic aspects of

CanscoradecussataRoem and Schult. Phcog Rev 2010;4:49-57.

14. Sethiya NK, Nahata A, Dixit VK. Anxiolytic activity of Canscoradecussata in albino rats.

J Compliment Integr Med 2010;7:19.

15. Ayurvedic Pharmacopoeia of India, Part- I, Volume II, pg-147.

16. An update on Shankhpushpi, a cognition boosting Ayurvedic medicine, NK Sethia et. al., Journal of Chinese integrative medicine, November 2009.

17. Bapalal Vaidya, NighantuAdarsh, Chaukhamba Bharti Academy, Reprint edition: 2009, pg-114.

18. DravyagunaVijnana II, Dr. JLN Shashtri, ChaukhambaOrientalia, Varanasi, Reprint edition: 2014, pg- 359- 60.

19. Bisht NPS, Singh R. Chemical studies of ConvulvulusmicrophyllusSieb. Planta Med. 1978; 34 (2): 222-223.

20. Shah SC, Quadry SJ. A textbook of pharmacognosy. $7^{\text {th }}$ edition. New Delhi: CBS Publishers. 1990: 388-389.

21. Deshpande SM, Srivastava DN. Chemical studies of ConvulvuluspluricaulisChoisy. J Indian Chem Soc. 1969; 46(8): 759-760.

22. Singh GK., Bhandari A. Text book of pharmacognosy. New Delhi: CBS publishers. 2000: 193-194.

23. Deshpande SM, Srivastava DN. Chemical examination of fatty acids of Convulvuluspluricaulis. Indian Oil Soap J. 1969; 34(2): 217-218.

24. Srivastava DN, Deshpande SM. Gas Chromatographic identification of fatty acids, fatty alcohols, and hydrocarbons of Convulvuluspluricaulis (Choisy). J am oil Chem Soc. 1975; 52 (8): 318-319.

25. Patil UK, Dixit VK. Densitometric standardization of herbal medical products containing Evolvulusalsinoides by quantification of scopoletin in Convulvuluspluricaulischoisy and in commercial for mulations of Shankhpushpi. J planar chromatograph. 2005; 18(3): 234-239

26. Kapadia NS, Acharya NS, Acharya SA, Shah MB. Use of HPTLC to establish a distinct chemical profile for Shankhpushpi and for Quantification of scopoletin in Convulvuluspluricaulischoisy and in commercial for mulations of Shankhpushpi J Planar chromatogr. 2006; 19(109): 195-199

27. Zafar R, Ahmad S, Mujeed M. Estimation of scopoletin in leaf and leaf callus of Convolvulus microphyllusSieb. Indian J pharm Sci. 2005; 67 (5): 600-603.

28. Dr. JLN Shashtri, DravyagunaVijnana II, ChaukhambaOrientalia, Varanasi, Reprint edition: 2014, pg- 359- 60.

29. Sharma PV. DravyagunVigyan. Chaukambha Bharti Academy, Varanasi. 2019.

30.Dhanvantari Nighantu, e-Nighantu, Collection of Ayurvedic Lexicons, CCRAS, New Delhi, Edition:2012, KarviradiVarga, sloke no. 111-112.

31. KaiyadevNighantu, e-Nighantu, Collection of Ayurvedic Lexicons, CCRAS, New Delhi, Edition:2012, AushadhiVarga, sloke no. 1493-97.

32. ShodhalNighantu, e-Nighantu, Collection of Ayurvedic Lexicons, CCRAS, New Delhi, Edition:2012, KarviradiVarga, sloke no. 541.

33. MadanpalNighantu, e-Nighantu, Collection of Ayurvedic Lexicons, CCRAS, New Delhi, Edition:2012, AbhyadiVarga, sloke no. 276-77.

34. BhavprakashNighantu, e-Nighantu, Collection of Ayurvedic Lexicons, CCRAS, New Delhi, Edition:2012, GuruchyadiVarga, sloke no. 269-70. 
35. Raj Nighantu, e-Nighantu, Collection of Ayurvedic Lexicons, CCRAS, New Delhi, Edition:2012, GuruchyadiVarga, sloke no. 131-33.

36. KashinathShashtri, CharakSmhita-II, Pt. Chaukhamba Bharti Academy, Reprint edition: 2011.

37. KavirajAtridevGupt, Astangharidayam, Chaukhamba Prakashan Varanasi, Reprint edition:2011.

38. Dr. Smt. ShailajaShrivastava, Sharangadhar Samhita, ChaukhambaOrientalia Varanasi, Reprint Edition: 2005.

39. Handa SS. 1994. Rasayana drugs, part II. Pharma Times 26:3;17-25.

40. Singh RH, Narsimhamurthy K, Singh G. 2008. Neuronutrient impact of AyurvedicRasayana therapy in brain aging. Biogerontol 9:6;369-74.

41. Gupta P, Siripurapu KB, Ahmad A, Palit G, Arora A, Maurya R. Anti-stress constituents of Evolvulusalsinoides: anAyurvedic drug. Chemical and Pharmaceutical Bulletin 2007; 55:771-775.

42. Chunekar KC. 1982. Bhavaprakasanighantu of Sri Bhavamisra. Commentary Varanasi (in Hindi) 455.

43. de Boer HJ, Ichim MC, Newmaster SG. DNA barcoding and pharmacovigilance of herbal medicines. Drug safety. 2015 Jul;38(7):611-20.

44. Grazina L, Amaral JS, Mafra I. Botanical origin authentication of dietary supplements by DNA-based approaches. Comprehensive Reviews in Food Science and Food Safety. 2020 May;19(3):1080-109.

45. Adewunmi CO, Ojewole JA. Safety of traditional medicines, complementary and alternative medicines in Africa. African journal of traditional, complementary and alternative medicines. 2004;1(1):1-3.

46. Srirama R, Kumar JS, Seethapathy GS, Newmaster SG, Ragupathy S, Ganeshaiah KN, Shaanker RU, Ravikanth G. Species adulteration in the herbal trade: causes, consequences and mitigation. Drug safety. 2017 Aug 1;40(8):651-61.

47. Gokhale, S. B., Joshi, P. V., Tatiya, A. U., Bakliwal, S. R., \&Fursule, R. A. Some neglected spices in India. 2004. 3(5), 343-346.

48. Yee, S. K., Chu, S. S., Xu, Y. M., \& Choo, P. L. Regulatory control of Chinese proprietary medicines in Singapore. Health policy. 2005. 71(2), 133-149.

49. Miller, G. M., \&Stripp, R. A study of western pharmaceuticals contained within samples of Chinese herbal/patent medicines collected from New York City's Chinatown. Legal Medicine.2007. 9(5), 258-264.

50. Joharchi, M. R., \&Amiri, M. S. Taxonomic evaluation of misidentification of crude herbal drugs marketed in Iran. Avicenna journal of phytomedicine. 2012. 2(2), 105.

51. Ernst, E., \& Coon, J. T. Heavy metals in traditional Chinese medicines: a systematic review. Clinical Pharmacology \& Therapeutics. 2001. 70(6), 497-504.

52. Ernst, E. Heavy metals in traditional Indian remedies. European journal of clinical pharmacology. 2002. 57(12), 891-896.

53. Ko RJ. Adulterants in Asian patent medicines. New England Journal of Medicine. 1998. 339(12), 847.

54. Obi, E., Akunyili, D. N., Ekpo, B., \&Orisakwe, O. E. Heavy metal hazards of Nigerian herbal remedies. Science of the total environment. 2006. 369(1-3), 35-41.

55. Caldas, E. D., \& Machado, L. L. Cadmium, mercury and lead in medicinal herbs in Brazil. Food and chemical toxicology. 2004. 42(4), 599-603.

56. García-Rico, L., Leyva-Perez, J., \&Jara-Marini, M. E. Content and daily intake of copper, zinc, lead, cadmium, and mercury from dietary supplements in Mexico. Food and chemical toxicology. 2007. 45(9), 1599-1605.

57. Ernst, E. Adulteration of Chinese herbal medicines with synthetic drugs: a systematic 
review. Journal of internal medicine. 2002. 252(2), 107-113.

58. Walker, K. M., \&Applequist, W. L. Adulteration of selected unprocessed botanicals in the US retail herbal trade. Economic botany. 2012. 66(4), 321-327.

59. Rathore, K. S. (2015). Standardisation and Evaluation of Herbal Drug Formulations.

60. Posadzki, P., Watson, L., \& Ernst, E. Contamination and adulteration of herbal medicinal products (HMPs): an overview of systematic reviews. European journal of clinical pharmacology. 2013. 69(3), 295-307.

61. Sagar, B. P., Zafar, R., Panwar, R., Kumar, V., \&Mangla, A. Herbal drugs standardization. The Indian Pharmacist. 2005. 4(35), 19-22.

62. Chen, S., Yao, H., Han, J., Liu, C., Song, J., Shi, L., ... \& Leon, C. Validation of the ITS2 region as a novel DNA barcode for identifying medicinal plant species. PloS one. 2010 5(1), e8613.

63. Mishra SH, Sethiya NK. Review on ethnomedicinal uses and phytopharmacology of memory boosting herb'Convolvuluspluricaulis' Choisy. Australian Journal of Medical Herbalism. 2010;22(1):19.

64. Nahata A, Patil UK, Dixit VK. Anxiolytic activity of Evolvulusalsinoides and Convulvulus pluricaulis in rodents. Pharm Biol 2009.47:5;444-51.

65. Malik J, Karan M, Vasisht K. Nootropic, anxiolytic and CNS-depressant studies on different plant sources of shankhpushpi. Pharmaceutical biology. 2011 Dec 1;49(12):123442.

66. Sharma VN, Barar FSK, Khanna NK, Mahawar MM. Some pharmacological actions of Convolvulus pluricaulis: an Indian indigenous herb. Ind J Med Res. 1965. 53:9;871-6.

67. Barar FSK, Sharma VN. Preliminary pharmacological studies on Convolvulus pluricaulisChois: an Indian indigenous herb. Indian J PhysiolPharmacol. 1966. 9:2;99-102.

68. Dhingra D, Valecha R. Evaluation of the antidepressant-like activity of Convolvulus pluricaulischoisy in the mouse forced swim and tail suspension tests. Medical science monitor. 2007 Jul 1;13(7):BR155-61.

69. Pawar SA, Dhuley JN, Naik SR. Neuropharmacology of an extract derived from Convolvulus microphyllus. Pharm Biol. 2001. 39:4;253-8.

70. Singh RH, Mehta AK. Studies on the psychotropic effect of the MedhyaRasayana drug 'Shankhpushpi' (Convolvulus pluricaulis) part 1 (Clinical Studies). J Res Ind Med YogHomeo. 1977. 12:3;18

71. Shukla SP. A comparative study on the barbiturate hypnosis potentiation effect of medhyarasayanadrugsshankhapushpi (Convolvulus pluricaulis). BMEBR 1981b. 1:4;554

72. Sinha PA, Kumar SP, Wahi A. Comparative pharmacognostic study on Shankhpushpi CanscoradecussataSchult, Convolvulus pleuricaulis Chios and Evolvulusalsinoides Linn. BMEBR 1986. 2;62-73.

73. Dandiya PC. The pharmacological basis of herbal drugs acting on CNS. Eastern Pharm. 1990. 33;39-47.

74. Dubey GP, Pathak SR, Gupta BS. Combined effect of Brahmi (Bacopamonniera) and Shankhpushpi (Convolvulus pluricaulis) on cognitive functions. Pharmacopsychoecol 1994. 7:3;249-51.

75. Sharma K, Arora V, Rana AC, Bhatnagar M. Anxiolytic effect of convolvulus pluricaulis petals on elevated plus maze model of anxiety in mice. J Herb Med \&Toxicol. 2009. 3:1;4146.

76. Panda S, Kar A. Inhibition of T3 production in levothyroxine-treated female mice by the root extract of Convolvulus pluricaulis. HormMetab Res. 2001 33:1;16-18.

77. Gupta RC, Singh PM, Prasad GC, Udupa KN. Probable Global dispensary Australian Journal of Medical Herbalism 2010 22(1) National Herbalists Association of Australia 2010 
25 mode of action of Shankhpushpi in the management of thyrotoxicosis. AncSci Life. 1981. $1 ; 49-53$.

78. Chaturvedi M, Mali PC, Dixit VP. Hypolipidaemic effect of Convolvulus microphyllus on cholesterol fed gerbils. J Phytological Res. 1997;8(2):153-5.

79.Bhakuni RS, Tripathi AK, Shukla YN, Singh SC. Insect antifeedant constituent from Convolvulus microphyllus (L) Sieb. Phytother Res. 1996. 10:2;170-1

80. Alam MM, Siddiqui MB, Hussain W. Treatment of diabetes through herbal drugs in rural India. Fitoterpia. 1990. 61:3;240-2.

81. Sairam K, Rao CV, Goel RK. Effect of Convolvulus pluricaulisChois on gastric ulceration and secretion in rats. Ind J Exp Biol. 2001. 39:4;350-4

82. Singh MP, Panda H. Medicinal herbs with their formulations 1st edn. Delhi: Daya Publishing. 2005

83. Rakhit S, Basu NK. Convolvulus pluricaulis. Indian Y Pharm. 1958;20:357-9.

84. Sharma VN, Barar FSK, Khanna NK, Mahawar MM. Some pharmacological actions of Convolvulus pluricaulis: an Indian indigenous herb. Ind J Med Res. 1965. 53:9;871-6.

85.. Chaturvedi GN, Sharma RK, Sen SP. Hypotensive effect of certain indigenous drugs with special reference to shankhapuspi (C. pluricaulis) in anaesthetised dogs. JRIM. 1966. $1: 1 ; 57-67$.

86. Heba M, Faraz S, Banerjee S. Effect of Shankhpushpi on alcohol addiction in mice. Pharmacognosy magazine. 2017 Jan;13(Suppl 1):S148.

87.Giradkar PN. Anthelmintic shankhpushpi pellets: taste masking. International Journal of Pharmaceutical Research and Bio-Science. 2015;4(4):129-56.

88. Mishra SH, Sethiya NK. Review on ethnomedicinal uses and phytopharmacology of memory boosting herb'Convolvuluspluricaulis' Choisy. Australian Journal of Medical Herbalism. 2010;22(1):19. 